\title{
ATTAINMENT OF SEXUAL MATURITY BY HYBRIDS OF RUDD, SCARDINIUS ERYTHROPHTHALMUS (L.) AND CARP BREAM, ABRAMIS BRAMA (L.) UNDER EXPERIMENTAL CONDITIONS
}

Wiesława KOPIEJEWSKA ${ }^{1 *}$, Janusz TERLECKI ${ }^{2}$, Łucjan CHYBOWSKI ${ }^{3}$

${ }^{1}$ Division of Zoology, University of Warmia and Mazury in Olsztyn, Olsztyn, Poland

${ }^{2}$ Division of Ecology and Hydrobiology, University of Warmia and Mazury in Olsztyn, Poland

${ }^{3}$ Institute of Inland Fisheries in Olsztyn, Division of Lake Fisheries in Giziycko, Poland

Kopiejewska W., Terlecki J., Chybowski L., 2004. Attainment of sexual maturity by hybrids of rudd, Scardinius erythrophthalmus (L.) and carp bream, Abramis brama (L.) under experimental conditions. Acta Ichthyol. Piscat. 34 (1): $43-50$.

Background. In case of natural hybridisation of fish it is important to determine whether the hybrids attain sexual maturity and whether they can produce generation $\mathrm{F}_{2}$. The hybrids of rudd and carp bream, relatively frequent under natural conditions, have not been studied in the aspect of sexual maturity attainment.

Material and methods. Histological examinations of gonads of 4-5 year old rudd and carp bream hybrids were carried out in experimental environments during the prespawning and spawning seasons of the parental species.

Results. In development of oocytes the female hybrids of rudd and carp bream reached the stage of migrating nucleus and deterioration of the morphological structure of the nucleus. In case of male hybrids the presence of spermatids was confirmed. The stage of spermatozoa was not observed in case of hybrids of rudd and bream. In case of the control species (rudd) that stage was also not observed. It is possible that the lack of that stage was affected by the parameters of the culture environment. Nevertheless, the sexual products of male hybrids of rudd and bream as well as rudd were deposited.

Conclusion. The studies show that the hybrids of rudd and carp bream may reach sexual maturity in the natural environments.

Key words: fish, Scardinius erythrophthalmus, Abramis brama, hybrids, attainment of sexual maturity.

\footnotetext{
* Correspondence: Dr Wiesława Kopiejewska, Katedra Zoologii, Uniwersytet Warmińsko-Mazurski w Olsztynie, ul. Oczapowskiego 5 , 10-957 Olsztyn, Poland; e-mail: w.kopiejewska@moskit.uwm.edu.pl
} 


\section{INTRODUCTION}

Natural hybridisation of cyprinid fishes is a common phenomenon in the Holarctic region (Hubbs 1955). In the European inland waters 62 combinations of natural hybrids within the family Cyprinidae are known, including 58 hybrids of the subfamily Leuciscinae (cf. Âkovlev et al. 2000). The hybrid of rudd, Scardinius erythrophthalmus (L.) and carp bream, Abramis brama (L.) is one of the most often recorded hybrids of that subfamily (Schwartz 1972, 1981, Kennedy and Fitzmaurice 1973, Brassington and Ferguson 1976, Economidis and Wheeler 1989, Terlecki 1997). In southern Ireland, Kennedy and Fitzmaurice (1973) specified 26 locations where that hybrid occurred and also indicated 13 locations for hybrids of roach and carp bream and one for roach and rudd. Schwartz $(1972,1981)$, in the bibliography referring to the hybridisation of fish species, has documented 31 reports on hybrids of A. brama $\times$ S. erythrophthalmus and 80 on hybrids of $A$. brama $\times R$. rutilus.

Haen and O'Rourke (1969a, b) identified hybrids of rudd and carp bream studying the proteins of the eye lenses and muscles. They found minor qualitative differences in proteins between rudd and bream and their hybrids. Also Brassington and Ferguson (1976), in their electrophoretic studies on identification of hybrids of rudd and bream, showed that except for one fraction in case of hybrids, the patterns of esterase of hybrids were the sum of the parental phenotypes. The authors ascertained no representatives of $\mathrm{F}_{2}$ generation of hybrid among the examined fish, which could, according to the authors, result from infertility of $F_{1}$ hybrids, too small number of examined fish or domination of the genes of one of the parental species.

Wheeler (1969) reports that hybrids of roach and bream and hybrids of roach and rudd are usually fertile. Fertility of the hybrids of roach and bream was confirmed by obtaining $F_{2}$ generation during experimental studies (Wood and Jordan 1987, Âkovlev et al. 2000). There is no reference on sexual maturation of hybrids of rudd and bream in the ichthyological literature.

The aim of this study was to determine whether the hybrids of rudd and bream reach sexual maturity.

\section{MATERIALS AND METHODS}

In 1998 artificial spawning of rudd, Scardinius erythrophthalmus and carp bream Abramis brama was carried out along with reciprocal hybridisation of those species. As a result the spawn of rudd fertilized with sperm of bream and spawn of female bream fertilized by sperm of male rudd yielded hybrids of rudd $\times$ bream and hybrids of bream $\times$ rudd, respectively. To obtain control individuals, the spawn of rudd was fertilized with sperm of male rudd. The rudd and bream used, represented respective natural populations of the lakes of north-eastern Poland. Artificial spawning of parental species and initial rearing of the obtained larvae and juveniles was carried out at the Dgał Experimental Hatchery at Pieczarki during the period from May to 
September (1998). A further rearing took place at the laboratory of the University of Warmia and Mazury in Olsztyn. Water temperature in tanks during the experiment (1998-2003) was constant and amounted to $10.9 \pm 2.85^{\circ} \mathrm{C}$ from November to April and $17.2 \pm 1.27^{\circ} \mathrm{C}$ from May to September. Juvenile fish were fed the Nutra feed $\left(\right.$ protein $/$ fat $\left.=54 / 18,19.5 \mathrm{MJ} \cdot \mathrm{kg}^{-1}\right)$.

In 2002 and 2003, during the period from April to July, gonads of the reciprocal hybrids of rudd and bream as well as rudd were collected for histological examination from the total of 177 individuals (Table 1).

Table 1

Number of fish examined

\begin{tabular}{lcccccc}
\hline \multirow{2}{*}{ Date } & \multicolumn{6}{c}{ Number of fish } \\
\cline { 2 - 7 } & \multicolumn{2}{c}{ rudd $x$ bream } & \multicolumn{2}{c}{ bream $\times$ rudd } & \multicolumn{2}{c}{ rudd } \\
\cline { 2 - 7 } & female & male & female & male & female & male \\
\hline 04 Apr 2002 & 6 & 12 & 8 & 9 & 4 & 13 \\
23 May 2002 & 1 & 8 & 7 & 3 & 1 & 9 \\
02 Jul 2002 & 4 & 5 & 6 & 4 & 1 & 9 \\
29 May 2003 & 9 & 11 & 8 & 5 & 3 & 7 \\
11 Jun 2003 & - & 4 & - & - & 2 & 8 \\
18 Jun 2003 & - & - & - & 3 & - & 7 \\
\hline Total & 20 & 40 & 29 & 24 & 11 & 53 \\
\hline
\end{tabular}

The gonads of fish were fixed in buffered formalin, dehydrated in a series of ethanol dilutions, exposed to chloroform, and embedded in paraffin. From the middle segments of the right and left gonad 5- $\mu \mathrm{m}$ thick sections were cut out. They were stained in Delafield's haematoxylin and eosin (Zawistowski 1986). Photographs of cross-sections of the gonads were taken using Olympus CX41 digital camera. The developmental stages of germinal cells and gonads were identified according to Sakun and Buckaâ (1968), West (1990), Bieniarz and Epler (1991), Tyler and Sumpter (1996) as well as Murua and Saborido-Rey (2003). In ovaries, the primary growth stage or protoplasmatic growth of oocytes is characterized by absence of yolk in the oocyte cytoplasm. The oocytes at that stage form a pool, from which only a part reaches maturity during the sexual cycle and that will be excreted during spawning. The stage of yolk vesicle (cortical alveoli) formation (endogenous vitellogenesis) is characterized by presence of yolk vesicles in the cytoplasm. The yolk vesicles at that stage increase their size and number developing a number of circumferential rings in the oocyte. The vitellogenic (yolk) stage is characterized by presence of yolk proteins in the form of granules and spheres. It develops during exogenous vitellogenesis. During that stage, oocytes significantly increase their diameter as a consequence of yolk accumulation. The oocyte mature stage starts with migration of the nucleus towards the micropyle. After completing the nuclear migration, the first meiotic division of the oocyte takes 
place as well as, in case of numerous species, hydration of oocyte before ovulation. The testicles at stage I of spermatogenesis contain mainly spermatogonia-large, round cells with the nucleus occupying almost the entire space leaving just a narrow space for cytoplasm. During stage II, spermatogonia are subject to mitotic division and the primary spermatocytes are visible. Stage III is characterized by presence of germinal cells at different stages of development, from spermatogonia to spermatocytes and spermatids. During stage IV, testes contain spermatozoa. During stage V the spermatic liquid thinning the concentrated spermatozoa is present. During stage VI (afterspawning), few spermatozoa and spermatogonia are present.

Group-synchronous or asynchronous type of oocytes development was identified based on the absence or presence of oocytes in the stage of yolk vesicle (cortical alveoli) formation during the period preceding reproduction and the percentage share of those oocytes in the group of trophoplasmatic growth oocytes. The proportional share of oocytes at different stages of development in the group of trophoplasmatic growth oocytes was determined according to the method described by Kopiejewska (2003) using the Abercrombie's formula (after Marrable 1962):

$$
N=\frac{T}{T+D} n
$$

where:

$N$, number of oocytes in a selected phase,

$T$, section thickness,

$D$, arithmetic mean of diameters of 20 oocytes in a selected phase,

$n$, number of sections of oocytes in a selected phase in three serial sections.

\section{RESULTS}

In 2002 and 2003, ovaries of the vast majority of the examined female hybrids contained oocytes at exogenous vitellogenesis and mature stags. In the remaining females, the ovaries contained primary growth oocytes or oocytes at the stage of commencement or continuation of yolk vesicle (cortical alveoli) formation. Oocytes in the mature stage were characterized by the migration of the nucleus towards the micropyle or lack of morphological structure of the nucleus (Fig. 1A, B). The diameters of those oocytes ranged from 950 to $1180 \mu \mathrm{m}$. In majority of females (both groups of hybrids (rudd $\times$ bream and bream $\times$ rudd) with oocytes in the mature stage, the development of oocytes was group-synchronous. Next to the oocytes at the mature stage, primary growth oocytes were present (Fig. 1A). In some females, however, the cortical alveoli stage oocytes were present next to the mature stage oocytes or late exogenous vitellogenesis oocytes (Fig. 1B). They represented from 63 to $81 \%$ of trophoplasmatic growth oocytes in females.

Their diameter was $275-315 \mu \mathrm{m}$ during the early stage and 400-650 $\mu \mathrm{m}$ during the advanced stage. Similarly, among female rudd, individuals with group-synchronous 



Fig. 1. Cross sections of ovaries: (A) an ovary with group-synchronous development of oocytes in hybrids of rudd $\mathrm{x}$ bream (ms, oocyte in mature stage, black arrow points at micropyles, white arrow at oocytes nucleus; pgs, oocyte in primary growth stage); (B) an ovary with asynchronous development of oocytes in hybrids of bream x rudd (ms, oocyte in mature stage, after breaking of the morphological structure of the nucleus; cas, oocyte in cortical alveoli stage; pgs, oocyte in primary growth stage); (C) atresia of mature oocytes in the ovary of a hybrid of rudd $\mathrm{x}$ bream; scale $=150 \mu \mathrm{m}$; (D) early oocytes stopped in development and atretic in the ovary of a hybrid of bream x rudd; scale $=50 \mu \mathrm{m}$ 

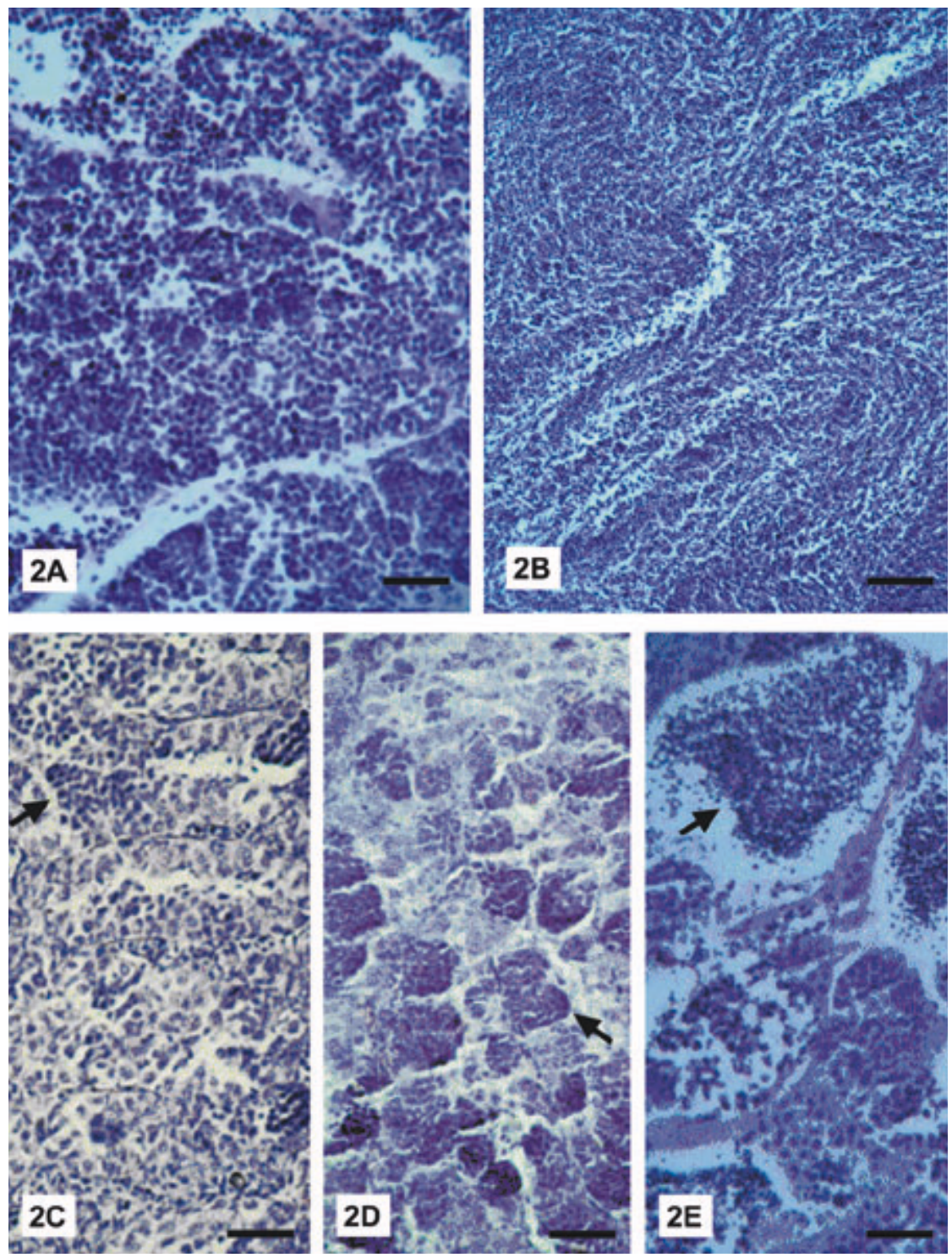

Fig. 2. Cross sections of testes: (A) testes at stage II of maturity with spermatocytes in hybrids of bream x rudd; (B) testes at stage IV of maturity with spermatids in rudd; (C) testes at stage II of maturity with spermatogonia and spermatocytes (arrow points at spermatocytes) in the hybrid of bream x rudd; (D) testes at stage II of maturity with spermatogonia and spermatocytes (arrow points at spermatocytes) in rudd; (E) testes at stage IV of maturity with spermatids and spermatocytes (arrow points at spermatids) in the hybrid of rudd $\mathrm{x}$ bream; scale $=50 \mu \mathrm{m}$ 
development of oocytes and individuals with asynchronous development of oocytes were found during the maturing of the oldest generation of oocytes. Oocytes at the cortical alveoli stage represented 23-36\% of trophoplasmatic growth oocytes while 64-77\% of oocytes were in the mature stage respectively. At the end of the period of the study, atresia of mature oocytes was observed in female hybrids of rudd and bream (Fig. 1C).

In case of $14 \%$ of female hybrids of bream $\times$ rudd occurrence of areas that stopped in the development and atretic oocytes were recorded. The features of the nuclei of cells that stopped development indicated stopping of the meiotic development during the early prophase I (Fig. 1D).

At the beginning of the study period, in April 2002, testes of male hybrids of rudd and bream as well as those of rudd contained spermatocytes. In May spermatocytes were present in all examined male hybrids of rudd and bream (Fig. 2A) while spermatids were present in all examined rudd males (Fig. 2B). At the beginning of July, testes of examined hybrids contained spermatogonia and few spermatocytes indicating newly produced generations (Fig. 2C). In the majority of male rudd spermatids were present while the others, similar to the hybrids, had spermatogonia and few spermatocytes (Fig. 2D). At the end of May 2003, testes of hybrids of rudd and bream contained spermatocytes and few spermatids. During the second half of June, larger quantities of spermatids were found in the hybrids (Fig. 2E). Spermatozoa were not observed in either the hybrids or rudd.

\section{DISCUSSION}

In this study, the presence of the final stages of maturing vitellogenic oocytes in female and spermatids in male hybrids of rudd and bream indicates the possibility of reaching sexual maturity by those hybrids under natural conditions. An absence of spermatozoa in hybrids could result from the conditions of artificial rearing as no presence of spermatozoa in rudd (the controls) was found. It could also result from gametic sterility that is found, among others, in hybrids of fish (Chevassus 1983). Nevertheless, the hybrids of rudd and bream and rudd controls excreted sexual products while the new sexual cycle started in the testes.

In this study, in both groups of hybrids: rudd $\times$ bream and bream $\times$ rudd, during the period when mature stage oocytes were present in ovaries, group-synchronous and asynchronous development of oocytes characteristic for rudd under the experiment conditions were present. In some reservoirs, spawning of rudd occurs in batches where ca. $80 \%$ of the entire spawn released during a given year matures during the first batch formation (Załachowski 2000). On the other hand bream in inland waters of Poland is a species in which group-synchronous development of oocytes (Brylińska and Długosz 1970) and one batch spawning (Brylińska and Tadajewska 2000) take place. As a consequence, it may be assumed that in case of rudd and bream hybrids features of both types of ovarian organization for parental species were present. Presence of asynchronous ovarian organization in both lines of rudd and bream hybrids suggests that the type of 
oocytes development may be passed by both female and male rudd. In asynchronous oocytes development in hybrids of rudd and bream, as different from rudd (64-77\%), mature oocytes were in minority in trophoplasmatic growth oocytes group (19-37\%).

In the studies carried out on reciprocal hybrids of rudd and bream, $14 \%$ of the female hybrids of bream x rudd had areas with germinal cells stopped at an early meiosis stage present among developing oocytes. Such concentrations of early oocytes stopped their development were also observed in case of the fertile hybrid of Clarias gariepinus and Heterobranchus longifilis (cf. Legendre et al. 1992). In hybrid of Notemigonus crysoleucas $\times$ Scardinius erythrophthalmus (cf. Goodwin et al. 1994) areas of oocytes with inappropriate appearance at the stage of nuclear chromatin were observed among developing oocytes. In female hybrids of Rutilus rutilus and Leuciscus idus (cf. Kopiejewska et al. 2003) reaching sexual maturity, gonia and degenerating cells were present in such areas.

\section{ACKNOWLEDGEMENTS}

The photographs were taken by Andrzej Koryzno, University of Warmia and Mazury, Olsztyn. The study was supported by grants No. 0208.805 (to W.K.) and 528-0803-0804 (to J.T.) from the University of Warmia and Mazury at Olsztyn.

\section{REFERENCES}

Âkovlev V.N., Slyn'ko Û.V., Grečanov I.G., Krysanov E.Û., 2000. Problema otdalennoj gibridizacii u ryb. Voprosy ihtiologii 40 (3): 312-326. (In Russian.)

Bieniarz K., Epler P., 1991. Rozród ryb. [Reproduction of fish.] Lettra, Kraków. (In Polish.)

Brassington R.A., Ferguson A., 1976. Electrophoretic identification of roach (Rutilus rutilus L.), rudd (Scardinius erythrophthalmus L.), bream (Abramis brama L.) and their natural hybrids. Journal of Fish Biology 9: 471-477.

Brylińska M., Długosz M., 1970. Rozwój jajnika leszcza (Abramis brama, L.) w cyklu rocznym. [Development of the ovaries of bream (Abramis brama, L.) in the year cycle.] Roczniki Nauk Rolniczych H 92 (1): 7-25. (In Polish.)

Brylińska M., Tadajewska M., 2000. Leszcz Abramis brama. [Bream, Abramis brama.] pp. 237-249. In: Brylińska M. (ed.) Ryby słodkowodne Polski. [The freshwater fishes of Poland.] PWN, Warszawa. (In Polish.)

Chevassus B., 1983. Hybridization in fish. Aquaculture 33: 245-262.

Economidis P.S., Wheeler A., 1989. Hybrids of Abramis brama with Scardinius erythrophthalmus and Rutilus rutilus from Lake Volvi, Macedonia, Greece. Journal of Fish Biology 35: 295-299.

Goodwin A.E., Grizzle J.M., Tave D., Gibson M.D., Barnett B., Fiegel D.H., Beavers B.F., 1994. Golden shiner (Notemigonus crysoleucas) $\times$ rudd (Scardinius erythrophthalmus) 
hybrids: gonad histology and spawning trials. Journal of the World Aquaculture Society 25 (2): 230-235.

Haen P.J., O'Rourke F.J., 1969a. Comparative electrophoretic studies of the water-soluble eyelens proteins of some Irish freshwater fishes. Proceedings of the Royal Irish Academy B 68: 67-75.

Haen P.J., O'Rourke F.J., 1969b. Comparative electrophoretic studies of the water-soluble muscle proteins of some Irish freshwater fishes. Proceedings of the Royal Irish Academy B 68: 101-108.

Hubbs C.L., 1955. Hybridization between fish species in nature. Systematic Zoology 4: 1-20.

Kennedy M., Fitzmaurice P., 1973. Occurrence of cyprinid hybrids in Ireland. Irish Naturalists Journal 17: 349-351.

Kopiejewska W., 2003. Determination of frequency distribution of oocytes at different maturity phases in the ovaries of roach, Rutilus rutilus (L.). Acta Ichthyologica et Piscatoria 33 (1): 47-53.

Kopiejewska W., Terlecki J., Chybowski Ł., 2003. Varied somatic growth and development of germinal cells in reciprocal hybrids of roach Rutilus rutilus (L.) and ide Leuciscus idus (L.). Archives of Polish Fisheries 11 (1): 33-44.

Legendre M., Teugels G.G., Cauty C., Jalabert B., 1992. A comparative study on morphology, growth rate and reproduction of Clarias gariepinus (Burchell, 1822), Heterobranchus longifilis Valenciennes, 1840, and their reciprocal hybrids (Pisces, Clariidae). Journal of Fish Biology 40: 59-79.

Marrable A.W., 1962. The counting of cells and nuclei in microtome sections. Quarterly Journal of Microscopial Science 103: 331-347.

Murua H., Saborido-Rey F., 2003. Female reproductive strategies of marine fish species of the North Atlantic. Journal of Northwest Atlantic Fishery Science 33: 23-31.

Sakun O.F., Buckaâ N.A., 1968. Opredelenie stadii zrelosti i izučenie polovyh ciklov ryb. [Determination of the maturity stages and studies on reproductive cycles of fishes.] Ministerstvo Rybnogo Hozâjstva SSSR, Polârnyj naučno-issledovatel'skij i proektnyj institut morskogo rybnogo hozâjstva i okeanografii im. Knipoviča, Murmansk. (In Russian.)

Schwartz F.J., 1972. World literature to fish hybrids, with an analysis by family, species, and hybrid. Publications of the Gulf Coast Research Laboratory Museum 32: 1-328.

Schwartz F.J., 1981. World literature to fish hybrids with an analysis by family, species, and hybrid. Supplement 1. NOAA Technical Report NMFS SSRF (750): 1-507.

Terlecki J., 1997. Przegląd problemów dotyczących międzyrodzajowych oraz międzygatunkowych mieszańców ryb z rodziny karpiowatych (Osteichthyes, Cyprinidae). [A review of problems related to intergeneric and interspecies hybrids of fish from the cyprinid family (Osteichthyes, Cyprinidae).] pp. 40-48. In: Anonymous (ed.) III sesja sympozjum, Systematyka i filogeneza swiata zwierzęcego; Sytematyka ryb karpiowatych Cyprinidae. [Systematics and phylogenesis of the animal kingdom. Systematics of cyprinid fishes, Cyprinidae.] Akademia Rolniczo-Techniczna w Olsztynie. (In Polish.)

Tyler C.R., Sumpter J.P., 1996. Oocyte growth and development in teleosts. Reviews in Fish Biology and Fisheries 6: 287-318.

West G., 1990. Methods of assessing ovarian development in fishes: a review. Australian Journal of Marine and Freshwater Research 41: 199-222.

Wheeler A., 1969. The fishes of the British Isles and North-West Europe. Macmillan, London. 
Wood A.B., Jordan D.R., 1987. Fertility of roach x bream hybrids, Rutilus rutilus (L.) $\times$ Abramis brama (L.), and their identification. Journal of Fish Biology 30: 249-261.

Załachowski W., 2000. Wzdręga Scardinius erythrophthalmus. [Rudd, Scardinius erythrophthalmus.] pp. 278-281. In: Brylińska M. (ed.) Ryby słodkowodne Polski. [The freshwater fishes of Poland.] PWN, Warszawa. (In Polish.)

Zawistowski S., 1986. Technika histologiczna, histologia oraz podstawy histopatologii. [Histological techniques, histology, and foundations of histopathology.] PZWL, Warszawa. (In Polish.)

Received: 10 September 2003 Accepted: 25 May 2004 